\title{
In-vitro analysis of the microbicidal activity of 6 contact lens care solutions
}

\author{
Claudia Hildebrandt ${ }^{1}$, Daniela Wagner ${ }^{1}$, Thomas Kohlmann² ${ }^{2}$ and Axel Kramer ${ }^{1 *}$
}

\begin{abstract}
Background: Contact lens-related infections are often associated with inadequate contact lens hygiene, and therefore, contact lens care products should be able to sufficiently minimise the amount of pathogens that are responsible for these infections. In 2001, the EN ISO 14729 was introduced to ensure adequate disinfection efficacy of contact lens care solutions, but this norm has recently been criticised.

Methods: In this study, six frequently used contact lens care solutions were retested according to the Stand Alone Test of the EN ISO 14729 (2001). The Stand Alone Test is a quantitative suspension test. In addition, the products were tested in a modified setting adding an organic load. The load was a mixture of human blood serum, lysozyme, and mucine, which resembles tear fluid.

Results: The criteria of the Stand Alone Test recommended in EN ISO 14729 were only met by Aosept Plus. This 3\% hydrogen-peroxide-based contact lens care solution attained a reduction factor of $>5$ log units for bacteria and $>4$ for fungi in all cases. Two further contact lens care solutions, Blue Vision and Optifree Replenish, met the criteria of a reduction factor of $>3 \log$ units for bacteria and $>1$ log unit for fungi, but only in the presence of artificial tear fluid. The three remaining products did not exhibit adequate disinfecting efficacy, at least against one of the tested microorganisms.

Conclusions: Through the observation that the artificial tear fluid used in this study influences the disinfecting efficacy of contact lens care solutions, especially that of multi-purpose solutions, in a different way than does albumin, mucine, or even the organic load suggested in EN ISO 14729, it becomes obvious that the test conditions in the EN ISO 14729 should be revised in order to create more realistic conditions, e.g., by using a more realistic artificial tear fluid. Furthermore, we suggest adapting the EN ISO 14729 to the European test hierarchy for chemical disinfectants and antiseptics, which consists of three test phases and also requests meeting stricter criteria in order to pass the test. Unless the test conditions guarantee a sufficient reduction of potential pathogens, the risk of contact lens-related microbial keratitis and other infections will remain for the users.
\end{abstract}

Keywords: Contact lens care solutions, Microbicidal activity, EN ISO 14729

\section{Background}

In developed countries, contact lens (CL) wear, especially hydrogel $\mathrm{CL}$ wear, is the most common risk factor for microbial keratitis [1-10] and has steadily increased over the past decades [11]. In the aetiology of CL-associated microbial keratitis, Pseudomonas spp. [11,12] dominate, followed by other bacteria species, fungi, and Acanthamoeba [5,11-29]. In many cases, infections are initiated by the CL wearers themselves. One of the major risk

\footnotetext{
* Correspondence: kramer@uni-greifswald.de

${ }^{1}$ Institute of Hygiene and Environmental Medicine, University Medicine Greifswald, Greifswald, Germany

Full list of author information is available at the end of the article
}

factors is the inadequate hygiene in handling CLs and their accessories [1,30-32]. Numerous studies have concluded that up to $90 \%$ of CL wearers are non-compliant with at least some of their CL care regimen [33-36]. This non-compliance is thought to result, for example, from the lack of understanding proper CL care procedures by the CL wearers [33], or from misinformation and misinterpretation of practitioners' instructions [36].

In the light of these findings, it is essential that CL care products, especially CL care solutions, should be designed to sufficiently decrease the amount of potential pathogens in order to minimise the risk of CL-related

\section{Biomed Central}

(c) 2012 Hildebrandt et al.; licensee BioMed Central Ltd. This is an Open Access article distributed under the terms of the Creative Commons Attribution License (http://creativecommons.org/licenses/by/2.0), which permits unrestricted use, distribution, and reproduction in any medium, provided the original work is properly cited. 
infections. CL care products should ideally have a certain level of 'excess efficacy', or safety margin [36,37]. Unfortunately, different CL care solutions do not even provide a minimum of safety for the wearer and had to be taken off the market as they were associated with $\mathrm{CL}$ related microbial keratitis [11,38-44]. In addition to these issues, numerous studies have shown that CLs, CL cases and CL care solutions can be loaded with up to $10^{7}$ colony forming units (CFU) of bacterial, amoebic and even viral pathogens $[18,25,45,46]$.

To improve the situation, the EN ISO 14729 [47] was introduced in 2001 to ensure the disinfection efficacy of $\mathrm{CL}$ care solutions. CL care solutions are required to be tested according to this harmonised norm, as they are classified as medical devices Class IIb according to 93/ 42/EEC [48] rule 15: All devices intended specifically to be used for disinfection, cleaning, rinsing or, when appropriate, hydrating contact lenses are in Class IIb.

However, the EN ISO 14729 was designed with the assumption that the CL wearers perform an adequate ruband-rinse regimen [49]. Nevertheless, especially for CL wearers who do not comply with their CL care regimen, it is crucial that CL care solutions not only meet the EN ISO Stand Alone primary criteria, but also exceed them under more realistic conditions [50-52]. Therefore, various studies have been conducted on the basis of EN ISO 14729 with an added organic load, with the result that most products failed, especially the multi-purpose solutions $[45,53]$.

In this study, six CL care solutions, mainly based on hydrogen peroxide, were retested according to the EN ISO 14729 [47]. There was special focus on creating a realistic setting by adding an organic load (artificial tear fluid) to the test conditions.

\section{Methods}

\section{Contact lens care solutions}

The CL care solutions listed in Table 1 were used according to the respective manufacturer's instructions. The CL care solutions were assessed before their stated expiration dates and were taken from their original packaging.

\section{Microorganisms}

The test organisms Pseudomonas aeruginosa (ATCC 9027), Staphylococcus aureus (ATCC 6538), Serratia marcescens (ATCC 13880), Candida albicans (ATCC 10231) and Fusarium solani (ATCC 36031) were grown according to EN ISO 14729 (2001) [47].

\section{Artificial tear fluid}

The artificial tear fluid was prepared by adding $0.5 \%$ of the tear-specific protein lysozyme (chicken egg lysozyme, Sigma Aldrich, Steinheim, Germany) and $0.1 \%$ of mucine (from porcine stomach, Sigma Adrich, Steinheim, Germany) to human blood serum. Human blood serum was used because of its similarity to natural tear fluid in terms of $\mathrm{pH}$, osmolarity, ionic strength, and protein composition [54-57]. The serum was obtained from healthy blood donors at the Department of Transfusion Medicine of the University of Greifswald (Germany). Donors gave informed consent to provide an additional blood sample of $8 \mathrm{ml}$ whole blood for research purposes. Fresh serum samples were collected daily in $10 \mathrm{ml}$ tubes and used immediately. The amount of artificial tear fluid required for the quantitative suspension tests to simulate realistic conditions was determined by using a dryweight method: hydrogel CLs were dried for $4 \mathrm{~h}$ using a desiccator and were weighed afterwards. The dried CLs were immersed in artificial tear fluid for $8 \mathrm{~h}$, then dried and weighed again. The mean value of the calculated differences was approximately $0.1 \mathrm{~g}$ for two CLs. Therefore, $0.1 \mathrm{ml}$ artificial fluid was determined for use in further quantitative suspension tests.

\section{Quantitative suspension test method}

The quantitative suspension tests were performed in accordance with EN ISO 14729 (2001) [47]. $0.1 \mathrm{ml}$ of broth culture (for bacteria ca. $10^{9} \mathrm{CFU} / \mathrm{ml}$, for yeast ca. $10^{8} \mathrm{CFU} / \mathrm{ml}$ ) was transferred into $10 \mathrm{ml} \mathrm{CL}$ care

Table 1 Contact lens care solutions

\begin{tabular}{|c|c|c|c|c|c|}
\hline trade name & $\begin{array}{l}\text { manufacturer/ } \\
\text { distributor }\end{array}$ & active ingredient & MMRDT & overnight & inactivation solution \\
\hline AOSEPT PLUS & Ciba Vision & $3.0 \% \mathrm{H}_{2} \mathrm{O}_{2}$ & $6 \mathrm{~h}$ & $8 \mathrm{~h}$ & Eye See neutralising solution* \\
\hline BlueVision & Ciba Vision & $3.0 \% \mathrm{H}_{2} \mathrm{O}_{2}$ & $6 \mathrm{~h}$ & $8 \mathrm{~h}$ & Eye See neutralising solution* \\
\hline Easy Sept & Bausch \& Lomb & $3.0 \% \mathrm{H}_{2} \mathrm{O}_{2}$ & $6 \mathrm{~h}$ & $8 \mathrm{~h}$ & Eye See neutralising solution* \\
\hline Oxysept Comfort & $\mathrm{AMO}$ & $3.0 \% \mathrm{H}_{2} \mathrm{O}_{2}$ & $6 \mathrm{~h}$ & $8 \mathrm{~h}$ & Eye See neutralising solution* \\
\hline Optifree Replenish & Alcon & $\begin{array}{l}0.001 \% \text { polyquad (polyquaternium- } 1 \text { ), } 0.0005 \% \text { aldox } \\
\text { (myristamidopropyl dimethylamine) }\end{array}$ & $6 \mathrm{~h}$ & $8 \mathrm{~h}$ & $\left.|A|\right|^{* *}$ \\
\hline Solocare Aqua & Ciba Vision & 0.0001\% polyhexanide & $4 \mathrm{~h}$ & $8 \mathrm{~h}$ & $\left.|A|\right|^{* *}$ \\
\hline
\end{tabular}

MMRDT - manufacturer's minimum recommended disinfection time.

* Eye See neutralising solution, Lapis Lazuli Int. NV: catalase, $0.01 \%$ EDTA, $0.002 \%$ merthiolate, isotonic buffer solution.

** inactivation solution II: 3\% TSB (Roth, Karlsruhe, Germany), 3\% polysorbate 80 (Serva, Heidelberg, Germany), 3\% saponin (Fluka, Buchs, Switzerland),

$0.1 \%$ L-histidine (Serva, Heidelberg, Germany), $0.1 \%$ L-cysteine (Merck, Darmstadt, Germany) in 1 L deionised water. 
solution and incubated at $25^{\circ} \mathrm{C}$ for the manufacturer's minimum recommended disinfection time (MMRDT) as well as overnight $(8 \mathrm{~h})$ (Table 1$)$. In a parallel series, all experiments were performed likewise with the addition of $0.1 \mathrm{ml}$ artificial tear fluid as the organic load.

After disinfection, the active ingredients were neutralised for 30 minutes at room temperature by transferring $1 \mathrm{ml}$ of the incubated CL care solution into $9 \mathrm{ml}$ of inactivation solution, which was individually assessed for each tested product (see Table 1). Afterwards, the serial dilutions were placed on the appropriate agar according to EN ISO 14729 [47]. Colonies were counted after $24 \mathrm{~h}$ (for bacteria and C. albicans) of incubation at $37^{\circ} \mathrm{C}$ and after $14 \mathrm{~d}$ (for F. solani) of incubation at $25^{\circ} \mathrm{C}$. Colony counting allowed calculation of the original viable bacterial cell concentration in $\log [\mathrm{CFU} / \mathrm{ml}])$; the results were reported as reduction factors of the log transformation data (RF log $[\mathrm{CFU} / \mathrm{ml}])$ by subtracting the CL care solution data from the control data. All experiments were performed for at least three different batches. According to EN ISO 14729 [47], the mean value of the reduction factors of these three batches was calculated. If the reduction factor of a batch was not an absolute value, e.g., $\geq 5.0 \log [\mathrm{CFU} / \mathrm{ml}]$, this data was assumed to be the absolute value for the calculation, i.e., $5.0 \mathrm{log}$ $[\mathrm{CFU} / \mathrm{ml}]$. If the results differed by more than $0.5 \mathrm{log}$ $[\mathrm{CFU} / \mathrm{ml}]$ from the mean value, the experiments were repeated. All in controls demanded by the norm were fulfilled.

\section{Statistical analyses}

Mean values and standard deviations of reduction factors are reported as descriptive statistics. For each CL care solution and for each tested microorganism, the proportion of reduction factors exceeding pre-specified thresholds were calculated. The thresholds were determined according to the criteria specified in the EN ISO 14729 Stand Alone Test recommendations [47]: $\geq 3.0$ $\log [\mathrm{CFU} / \mathrm{ml}]$ for bacteria and $\geq 1.0 \mathrm{log}[\mathrm{CFU} / \mathrm{ml}]$ for fungi. The thresholds $\geq 5.0 \mathrm{log}[\mathrm{CFU} / \mathrm{ml}]$ for bacteria according to the criteria in the norms EN 1040 [58], EN 13727 [59] and EN 1276 [60] and $\geq 4.0 \mathrm{log}$ [CFU/ml] for fungi according to the criteria in the norms EN 1275 [61], EN 13624 [62] and EN 1650 [63] were additionally assessed for comparative purposes. The criteria of the different norms were considered as met if the thresholds were attained to at least $50 \%$. Differences between proportions of reduction factors for CL care solutions were tested using the chi-square $\left(\chi^{2}\right)$ test. In addition to analyses of the complete data set (1), subgroup analyses of tests with vs. without organic load (2) and MMRDT vs. overnight (3) were performed. P-values $\leq 0.05$ were considered statistically significant.

\section{Results}

The disinfection efficacies of the six different CL care solutions (Table 1) are reported in Table 2 without and in Table 3 with artificial tear fluid as the organic load, and additionally in Figure 1 without and in Figure 2 with organic load. All these data are the mean values of RF with standard deviation. Further, the calculated proportions of RFs exceeding the pre-specified thresholds are reported in Table 4 for each CL care solution and each microorganism. Table 5 shows these proportions without organic load and Table 6 with organic load. Reduction factor results by the different disinfecting times MMRDT and overnight are shown in Tables 7 and 8, respectively.

The primary criteria of the Stand Alone Test recommended in EN ISO 14729 [47] require a RF of $\geq 3 \mathrm{log}$ units for bacteria and $\geq 1 \log$ unit for fungi. The results show that only Aosept Plus met these criteria and even exceeded them with $>6 \log$ units for bacteria and $>4$ $\log$ units for fungi without organic load (Tables 2 and 5). With organic load, the product yields lower yet sufficient RFs of $>5$ for $S$. aureus and $S$. marcescens, and unchanged high RFs for all other microorganisms. The harmonised requirements for determining the efficacies of chemical disinfectants and antiseptics, i.e., a RF of $\geq 5$ $\log$ units for bacteria and $\geq 4 \log$ units for fungi, are solely met by Aosept Plus regardless of the test conditions (Tables 4, 5, 6, 7, 8).

Although Blue vision, Easy Sept and Oxysept Comfort also contain $3 \%$ hydrogen peroxide, these three products yielded different results. BlueVision does not pass the Stand Alone criteria due to insufficient efficacy against $S$. aureus. The efficacy against the other microorganisms is particularly high, with a RF $>7 \log$ units for bacteria and $>4 \log$ unit for fungi. In the presence of organic load, the efficacy of BlueVison against $S$. aureus increases dramatically, while that against all other microoraganisms is not affected by the organic load in any way. The great increase of efficacy against $S$. aureus enables the product to pass the Stand Alone criteria in the presence of organic load. The criteria of the harmonised norms for chemical disinfectants and antiseptics, however, are still not met.

Without organic load, Easy Sept and Oxysept Comfort exhibited behaviour similar to BlueVision, showing a lack of efficacy against $S$. aureus and therefore not passing the Stand Alone Test either. The positive effect of organic load on the efficacy of BlueVision against $S$. aureus can only be be slightly observed for Easy Sept. The efficacy of Oxysept Comfort decreases even further. This means that Easy Sept and Oxysept Comfort do not fulfill the requirements of the Stand Alone Test, either with or without organic load. Consequently, the criteria of the harmonised norms for chemical disinfectants and antiseptics also cannot be met. 
Table 2 Mean values of reduction factors of six different contact lens care solutions in log [CFU/ml] without organic load. Standard deviations are given in parentheses

\begin{tabular}{|c|c|c|c|c|c|c|}
\hline $\mathrm{CL}$ care solution & Time & S. aureus & P. aeruginosa & S. marcescens & C. albicans & F. solani \\
\hline \multirow[t]{2}{*}{ Aosept Plus } & $6 \mathrm{~h}$ & $>6.7(0.23)$ & $>7.0(0.21)$ & $>7.0(0.10)$ & $>4.2(0.20)$ & $>5.0(0.06)$ \\
\hline & $8 \mathrm{~h}$ & $>6.7(0.23)$ & $>7.0(0.21)$ & $>7.0(0.10)$ & $>4.2(0.20)$ & $>5.0(0.06)$ \\
\hline \multirow[t]{2}{*}{ BlueVision } & $6 \mathrm{~h}$ & $1.3(0.15)$ & $>7.0(0.21)$ & $>7.0(0.10)$ & $>4.2(0.20)$ & $>5.0(0.06)$ \\
\hline & $8 \mathrm{~h}$ & $1.2(0.12)$ & $>7.0(0.21)$ & $>7.0(0.10)$ & $>4.2(0.20)$ & $>5.0(0.06)$ \\
\hline \multirow[t]{2}{*}{ Easy Sept } & $6 \mathrm{~h}$ & $1.5(0.35)$ & $>7.0(0.21)$ & $>7.0(0.10)$ & $>4.2(0.20)$ & $>5.0(0.06)$ \\
\hline & $8 \mathrm{~h}$ & $1.3(0.15)$ & $>7.0(0.21)$ & $>7.0(0.10)$ & $>4.2(0.20)$ & $>5.0(0.06)$ \\
\hline \multirow[t]{2}{*}{ Oxysept Comfort } & $6 \mathrm{~h}$ & $2.3(0.17)$ & $>7.0(0.21)$ & $>7.0(0.10)$ & $>4.2(0.20)$ & $>5.0(0.06)$ \\
\hline & $8 \mathrm{~h}$ & $2.3(0.29)$ & $>7.0(0.21)$ & $>7.0(0.10)$ & $>4.2(0.20)$ & $>5.0(0.06)$ \\
\hline \multirow[t]{2}{*}{ Optifree Replenish } & $6 \mathrm{~h}$ & $2.4(0.35)$ & $5.2(2.16)$ & $3.5(0.66)$ & $2.1(1.18)$ & $4.4(1.20)$ \\
\hline & $8 \mathrm{~h}$ & $2.5(0.25)$ & $>7.1(0.17)$ & $4.5(1.21)$ & $2.8(1.22)$ & $>4.9(0.20)$ \\
\hline \multirow[t]{2}{*}{ Solocare Aqua } & $4 \mathrm{~h}$ & $0.3(0.06)$ & $1.6(0.15)$ & $0.5(0.29)$ & $2.6(1.82)$ & $3.5(1.44)$ \\
\hline & $8 \mathrm{~h}$ & $0.4(0.21)$ & $1.5(0.21)$ & $0.6(0.29)$ & $2.9(1.65)$ & $4.0(1.35)$ \\
\hline
\end{tabular}

Although the RFs for the polyquad-based CL care product Optifree Replenish are generally lower than those of the hydrogen-peroxide-based products, the requirements of $>3 \log$ units for bacteria and $>1 \log$ unit for fungi are met in the presence of organic load. This again shows how the organic load can have a positive influence on the efficacy of the product. Without organic load, the product exhibits mostly lower RFs for bacteria than with organic load and in the case of $S$. aureus fails to meet the test criteria.

Solocare Aqua, the polyhexanide-based product, exhibits the lowest RFs in all cases. The product passes the Stand Alone Test neither with nor without organic load. Nevertheless, the influence of organic load, can be observed for Solocare Aqua as well: especially the efficacy against $P$. aeruginosa increases greatly by more than $2 \log$ units. On C. albicans, the organic load has a noticeable negative influence, reducing the efficacy by nearly $2 \log$ units.

Neither of the multi-purpose solutions (MPSs), Optifree Replenish and Solocare Aqua, meet the criteria of the harmonised norms for chemical disinfectants and antiseptics.

The prolonged disinfection time (overnight) did not noticeably influence the disinfection efficacy compared to the MMRDT for any of the tested CL care solutions. The $\chi^{2}$ test shows that in most cases, the disinfection efficacies significantly differ between the different CL care solutions.

\section{Discussion}

Many studies in the past have determined the disinfecting efficacy of polyhexanide- or polyquad-based multipurpose solutions (MPSs) and hydrogen-peroxide-based CL care solutions according to the primary criteria of

Table 3 Mean values of reduction factors of six different contact lens care solutions in log [CFU/ml] with organic load. Standard deviations are given in parentheses

\begin{tabular}{|c|c|c|c|c|c|c|}
\hline $\mathrm{CL}$ care solution & Time & S. aureus & P. aeruginosa & S. marcescens & C. albicans & F. solani \\
\hline \multirow[t]{2}{*}{ Aosept Plus } & $6 \mathrm{~h}$ & $5.5(2.01)$ & $>7.1(0.12)$ & $5.2(2.05)$ & $>5.3(0.06)$ & $>5.0(0.06)$ \\
\hline & $8 \mathrm{~h}$ & $5.7(1.81)$ & $>7.1(0.12)$ & $5.2(2.11)$ & $>5.3(0.06)$ & $>5.0(0.06)$ \\
\hline \multirow[t]{2}{*}{ BlueVision } & $6 \mathrm{~h}$ & $5.0(1.39)$ & $>7.1(0.12)$ & $>7.0(0.15)$ & $>5.3(0.06)$ & $>5.0(0.06)$ \\
\hline & $8 \mathrm{~h}$ & $4.8(1.64)$ & $>7.1(0.12)$ & $>7.0(0.15)$ & $>5.3(0.06)$ & $>5.0(0.06)$ \\
\hline \multirow[t]{2}{*}{ Easy Sept } & $6 \mathrm{~h}$ & $2.5(1.05)$ & $>7.1(0.12)$ & $>7.0(0.15)$ & $>5.3(0.06)$ & $>5.0(0.06)$ \\
\hline & $8 \mathrm{~h}$ & $2.3(0.82)$ & $>7.1(0.12)$ & $>7.0(0.15)$ & $>5.3(0.06)$ & $>5.0(0.06)$ \\
\hline \multirow[t]{2}{*}{ Oxysept Comfort } & $6 \mathrm{~h}$ & $1.7(0.17)$ & $>7.1(0.12)$ & $>7.0(0.15)$ & $>5.3(0.06)$ & $>5.0(0.06)$ \\
\hline & $8 \mathrm{~h}$ & $1.6(0.25)$ & $>7.1(0.12)$ & $>7.0(0.15)$ & $>5.3(0.06)$ & $>5.0(0.06)$ \\
\hline \multirow[t]{2}{*}{ Optifree Replenish } & $6 \mathrm{~h}$ & $3.4(0.55)$ & $>7.1(0.10)$ & $5.0(1.55)$ & $1.1(0.35)$ & $4.2(1.76)$ \\
\hline & $8 \mathrm{~h}$ & $3.5(0.34)$ & $>7.1(0.10)$ & $5.3(1.28)$ & $1.3(0.36)$ & $4.5(1.08)$ \\
\hline \multirow[t]{2}{*}{ Solocare Aqua } & $4 \mathrm{~h}$ & $0.9(0.40)$ & $3.5(2.24)$ & $0.9(0.20)$ & $0.8(0.25)$ & $3.7(1.24)$ \\
\hline & $8 \mathrm{~h}$ & $1.1(0.34)$ & $4.1(2.03)$ & $1.2(0.32)$ & $1.0(0.30)$ & $4.2(1.06)$ \\
\hline
\end{tabular}




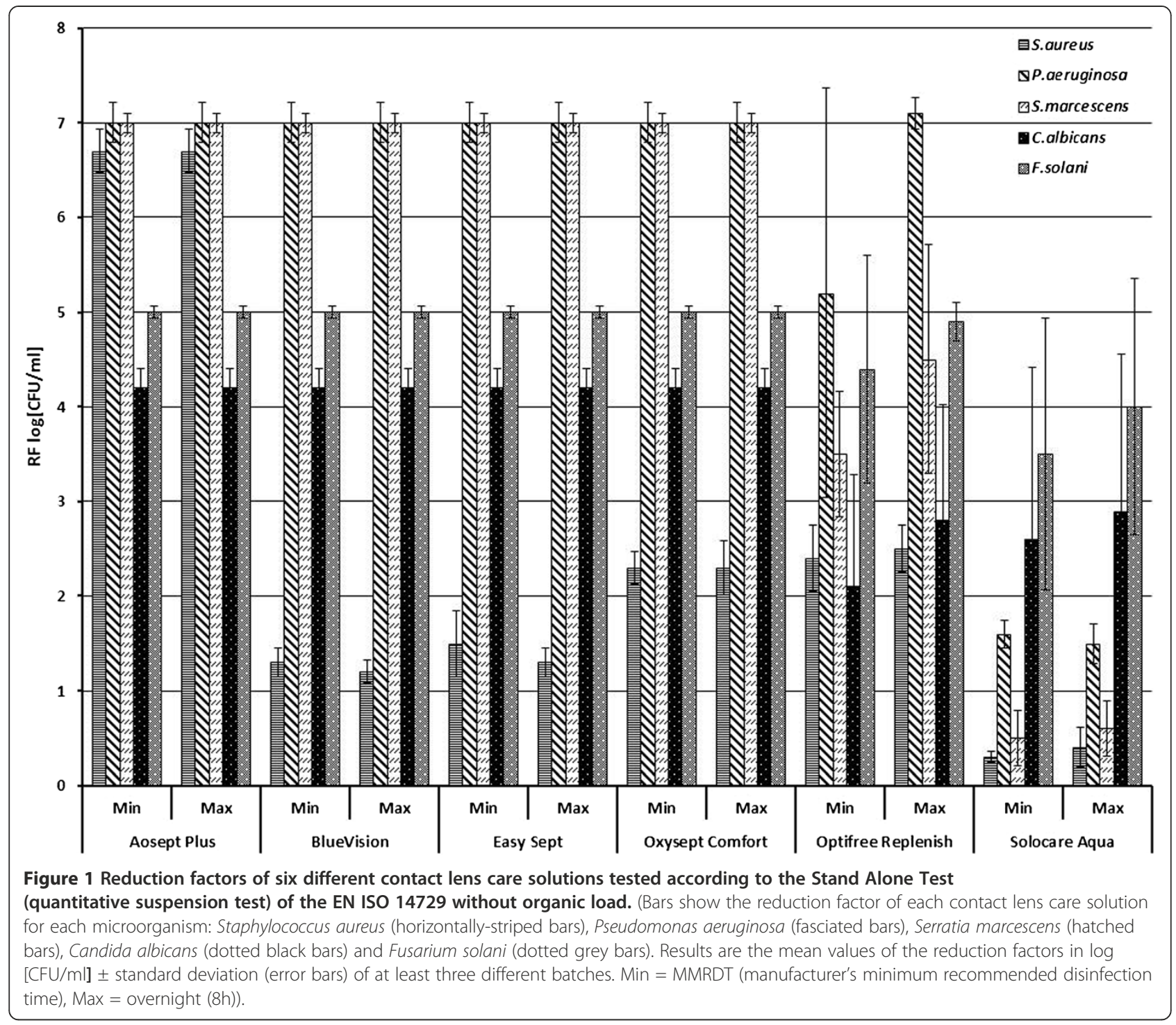

the Stand Alone Test of the EN ISO 14729 [41,45,5053,64-73]. Kramer et al. [45] and other authors [53,65,73] investigated the disinfecting efficacy of various CL care solutions including MPSs and hydrogen-peroxide-based $\mathrm{CL}$ care solutions, and reported that the hydrogenperoxide-based CL care solution Aosept Plus proved to be the most effective product, yielding reduction factors of $>5 \log$ units. This study also confirms that Aosept Plus, a 3\% hydrogen-peroxide-based CL care solution, yields the best results independent of all influencing factors, meets the primary criteria of the Stand Alone Test, and furthermore fulfills the harmonised requirements for determining the efficacies of chemical disinfectants and antiseptics. For more than 20 years now, it is known that CL care solutions based on 3\% hydrogen peroxide are mostly effective against a broad range of microorganisms [74,75] also in practical settings
[76,77], but it is also known that their efficacies can vary $[45,53]$. This study found differences in the efficacies against $S$. aureus, although the four tested hydrogen peroxide solutions have identical concentrations of active ingredient. The same effect has been observed for MPSs which are based on the same amount of active ingredient, for example $0.0001 \%$ polyhexanide $[45,53,73]$. Therefore, further ingredients such as salts, buffers, surfactants, sequestering agents, or wetting agents as well as the physical and chemical characteristics of the tested CL care solutions must be major influencing factors and must have the ability to increase the disinfection efficacies of CL care solutions [12,69,78-81]. Thus, the active ingredient itself is not a guarantee for sufficient disinfecting performance, and proof of efficacy by meeting a harmonised norm is essential. 


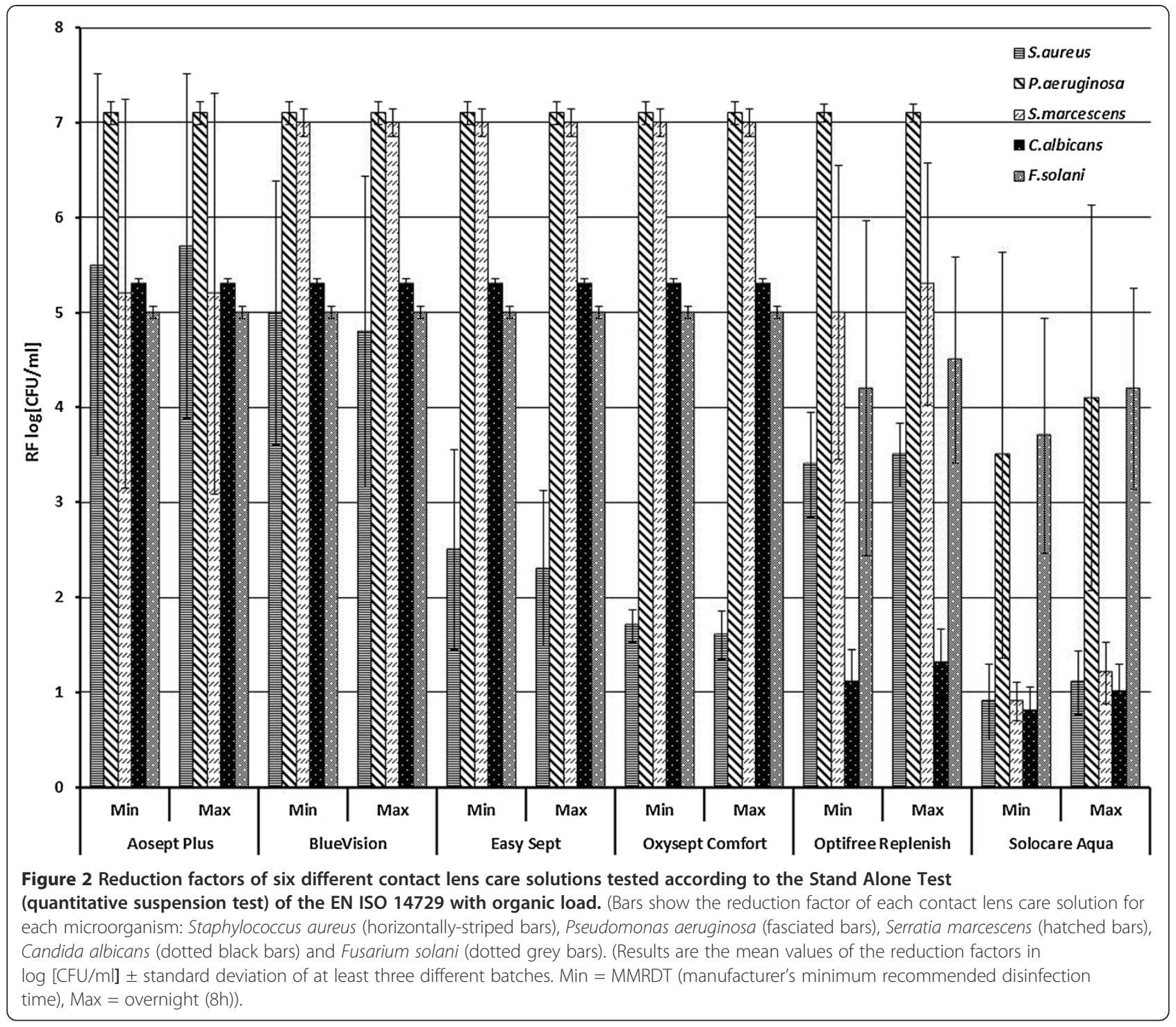

Table 4 Proportions of reduction factors exceeding pre-specified thresholds for each CL care solution and for each tested microorganism / complete data set

\begin{tabular}{|c|c|c|c|c|c|c|c|c|c|c|c|c|c|c|c|c|c|c|c|c|}
\hline & \multicolumn{4}{|c|}{ S. aureus } & \multicolumn{4}{|c|}{ P. aeruginosa } & \multicolumn{4}{|c|}{ S. marcescens } & \multicolumn{4}{|c|}{ C. albicans } & \multicolumn{4}{|c|}{ F. solani } \\
\hline & \multicolumn{2}{|c|}{$\mathrm{RF} \geq 3$} & \multicolumn{2}{|c|}{$\mathrm{RF} \geq 5$} & \multicolumn{2}{|c|}{$\mathrm{RF} \geq 3$} & \multicolumn{2}{|c|}{$\mathrm{RF} \geq 5$} & \multicolumn{2}{|c|}{$\mathrm{RF} \geq 3$} & \multicolumn{2}{|c|}{$\mathrm{RF} \geq 5$} & \multicolumn{2}{|c|}{$\mathrm{RF} \geq 1$} & \multicolumn{2}{|c|}{$\mathrm{RF} \geq 4$} & \multicolumn{2}{|c|}{$\mathrm{RF} \geq 1$} & \multicolumn{2}{|c|}{$\mathrm{RF} \geq 4$} \\
\hline & $\%$ & $\mathrm{~N}$ & $\%$ & $\mathrm{~N}$ & $\%$ & $\mathbf{N}$ & $\%$ & $\mathbf{N}$ & $\%$ & $\mathrm{~N}$ & $\%$ & $\mathrm{~N}$ & $\%$ & $\mathrm{~N}$ & $\%$ & $\mathrm{~N}$ & $\%$ & $\mathrm{~N}$ & $\%$ & $\mathrm{~N}$ \\
\hline AOSEPT PLUS & 88.9 & 18 & 77.8 & 18 & 100 & 12 & 100 & 12 & 88.9 & 18 & 66.7 & 18 & 100 & 12 & 100 & 12 & 100 & 12 & 100 & 12 \\
\hline BlueVision & 61.1 & 18 & 22.2 & 18 & 100 & 12 & 100 & 12 & 100 & 12 & 100 & 12 & 100 & 12 & 100 & 12 & 100 & 12 & 100 & 12 \\
\hline Easy Sept & 11.1 & 18 & 0 & 18 & 100 & 12 & 100 & 12 & 100 & 12 & 100 & 12 & 100 & 12 & 100 & 12 & 100 & 12 & 100 & 12 \\
\hline Oxysept Comfort & 0 & 12 & 0 & 12 & 100 & 12 & 100 & 12 & 100 & 12 & 100 & 12 & 100 & 12 & 100 & 12 & 100 & 12 & 100 & 12 \\
\hline Optifree Replenish & 61.1 & 18 & 0 & 18 & 94.4 & 18 & 83.3 & 18 & 95.8 & 24 & 20.8 & 24 & 94.4 & 18 & 16.7 & 18 & 95.8 & 24 & 87.5 & 24 \\
\hline Solocare Aqua & 0 & 18 & 0 & 18 & 38.9 & 18 & 11.1 & 18 & 0 & 12 & 0 & 12 & 77.8 & 18 & 22.2 & 18 & 100 & 24 & 58.3 & 24 \\
\hline$x^{2}$ test & \multicolumn{2}{|c|}{$<0.001$} & \multicolumn{2}{|c|}{$<0.001$} & \multicolumn{2}{|c|}{$<0.001$} & \multicolumn{2}{|c|}{$<0.001$} & \multicolumn{2}{|c|}{$<0.001$} & \multicolumn{2}{|c|}{$<0.001$} & \multicolumn{2}{|c|}{0.041} & \multicolumn{2}{|c|}{$<0.001$} & \multicolumn{2}{|c|}{0.695} & \multicolumn{2}{|c|}{$<0.001$} \\
\hline
\end{tabular}

The intervals $\geq 3.0 \mathrm{log}[\mathrm{CFU} / \mathrm{ml}$ ] for bacteria and $\geq 1.0 \mathrm{log}$ [CFU/ml] for fungi were assessed according to the criteria of the EN ISO 14729 Stand Alone Test [47]. The intervals $\geq 5.0 \mathrm{log}$ [CFU/ml] for bacteria according to the criteria of the norms EN 1040 [58], EN 13727 [59] and EN 1276 [60] and $\geq 4.0$ log [CFU/ml] for fungi according to the criteria of the norms EN 1275 [61], EN 13624 [62] and EN 1650 [63] were assessed. 
Table 5 Proportions of reduction factors exceeding pre-specified thresholds for each CL care solution and for each tested microorganism / without organic load

\begin{tabular}{|c|c|c|c|c|c|c|c|c|c|c|c|c|c|c|c|c|c|c|c|c|}
\hline & \multicolumn{4}{|c|}{ S. aureus } & \multicolumn{4}{|c|}{ P. aeruginosa } & \multicolumn{4}{|c|}{ S. marcescens } & \multicolumn{4}{|c|}{ C. albicans } & \multicolumn{4}{|c|}{ F. solani } \\
\hline & \multicolumn{2}{|c|}{$\mathrm{RF} \geq 3$} & \multicolumn{2}{|c|}{$\mathrm{RF} \geq 5$} & \multicolumn{2}{|c|}{$\mathrm{RF} \geq 3$} & \multicolumn{2}{|c|}{$\mathrm{RF} \geq 5$} & \multicolumn{2}{|c|}{$\mathrm{RF} \geq 3$} & \multicolumn{2}{|c|}{$\mathrm{RF} \geq 5$} & \multicolumn{2}{|c|}{$\mathrm{RF} \geq 1$} & \multicolumn{2}{|c|}{$\mathrm{RF} \geq 4$} & \multicolumn{2}{|c|}{$\mathrm{RF} \geq 1$} & \multicolumn{2}{|c|}{$\mathrm{RF} \geq 4$} \\
\hline & $\%$ & $\bar{N}$ & $\%$ & $\bar{N}$ & $\%$ & $\bar{N}$ & $\%$ & $\bar{N}$ & $\%$ & $\bar{N}$ & $\%$ & $\bar{N}$ & $\%$ & $\bar{N}$ & $\%$ & $\bar{N}$ & $\%$ & $\bar{N}$ & $\%$ & $\mathrm{~N}$ \\
\hline AOSEPT PLUS & 100 & 6 & 100 & 6 & 100 & 6 & 100 & 6 & 100 & 6 & 100 & 6 & 100 & 6 & 100 & 6 & 100 & 6 & 100 & 6 \\
\hline BlueVision & 0 & 6 & 0 & 6 & 100 & 6 & 100 & 6 & 100 & 6 & 100 & 6 & 100 & 6 & 100 & 6 & 100 & 6 & 100 & 6 \\
\hline Easy Sept & 0 & 6 & 0 & 6 & 100 & 6 & 100 & 6 & 100 & 6 & 100 & 6 & 100 & 6 & 100 & 6 & 100 & 6 & 100 & 6 \\
\hline Oxysept Comfort & 0 & 6 & 0 & 6 & 100 & 6 & 100 & 6 & 100 & 6 & 100 & 6 & 100 & 6 & 100 & 6 & 100 & 6 & 100 & 6 \\
\hline Optifree Replenish & 0 & 6 & 0 & 6 & 91.7 & 12 & 75 & 12 & 91.7 & 12 & 8.3 & 12 & 100 & 12 & 25 & 12 & 100 & 12 & 91.7 & 12 \\
\hline Solocare Aqua & 0 & 6 & 0 & 6 & 0 & 6 & 0 & 6 & 0 & 6 & 0 & 6 & 91.7 & 12 & 33.3 & 12 & 100 & 12 & 58.3 & 12 \\
\hline$x^{2}$ test & \multicolumn{2}{|c|}{$<0.001$} & \multicolumn{2}{|c|}{$<0.001$} & \multicolumn{2}{|c|}{$<0.001$} & \multicolumn{2}{|c|}{$<0.001$} & \multicolumn{2}{|c|}{$<0.001$} & \multicolumn{2}{|c|}{$<0.001$} & \multicolumn{2}{|c|}{0.690} & \multicolumn{2}{|c|}{$<0.001$} & & \multicolumn{2}{|c|}{0.024} \\
\hline
\end{tabular}

The intervals $\geq 3.0 \mathrm{log}$ [CFU/ml] for bacteria and $\geq 1.0 \mathrm{log}$ [CFU/ml] for fungi were assessed according to the criteria of the EN ISO 14729 Stand Alone Test [47]. The intervals $\geq 5.0$ log [CFU/ml] for bacteria according to the criteria of the norms EN 1040 [58], EN 13727 [59] and EN 1276 [60] and $\geq 4.0$ log [CFU/ml] for fungi according to the criteria of the norms EN 1275 [61], EN 13624 [62] and EN 1650 [63] were assessed.

Comparing MPSs, it has often been reported that polyquad-based CL care solutions such as Optifree are more effective than polyhexanide-based CL care solutions $[41,53,70,72]$, which is in line with the findings of this study. In particular Solocare Aqua seems to possess hardly any antimicrobial and antifungal characteristics [53]. These findings are in agreement with those of a recent in-vivo study by Nzeako et al. [12], who examined the microbial contamination of various commonly used CL care solutions. MPSs, especially those based on polyhexanide or related active ingredients, were found to be contaminated with Gram-negative bacteria, in particular P. aeruginosa, yeasts (Candida spp.), moulds, and Grampositive bacteria (especially $S$. marcescens) as well. The high number of contaminated MPSs reported in in-vivo studies $[12,25,45,46]$ and the association of MPSs with an increased risk of CL-related microbial keratitis [38-44] suggest that MPSs - especially those based on polyhexanide or related active ingredients -should be improved to yield higher antimicrobial and antifungal characteristics, and therefore should be tested under more realistic conditions before being placed on the market.

Especially the influence of the tear fluid and its components is an important factor for simulating more realistic conditions. Thus, different studies have reappraised the effect of organic load on test results $[45,53,72,82]$, for example, $0.2 \%$ bovine albumin [45], $0.2 \%$ mucine [73] or even more contaminated conditions with $1 \%$ albumin and $0.1 \%$ mucine [53]. All these studies exhibit similar results; organic load has a negative effect on the disinfecting efficacy of a number of CL care solutions. Still another organic load was used in this study: a special artificial tear fluid consisting of human blood serum, lysozyme and mucine to mimic realistic test settings. Although human blood serum represents a useful analogue to human tear fluid, serum has a higher protein concentration, lower quantities of antimicrobial substances, and lacks tear-specific proteins. Therefore, the tear-specific proteins lysozyme and mucine were added. This study revealed that in the presence of the described artificial tear fluid, the disinfecting efficacy against $S$. aureus

Table 6 Proportions of reduction factors exceeding pre-specified thresholds for each CL care solution and for each tested microorganism / with organic load

\begin{tabular}{|c|c|c|c|c|c|c|c|c|c|c|c|c|c|c|c|c|c|c|c|c|}
\hline & \multicolumn{4}{|c|}{ S. aureus } & \multicolumn{4}{|c|}{ P. aeruginosa } & \multicolumn{4}{|c|}{ S. marcescens } & \multicolumn{4}{|c|}{ C. albicans } & \multicolumn{4}{|c|}{ F. solani } \\
\hline & \multicolumn{2}{|c|}{$\mathrm{RF} \geq 3$} & \multicolumn{2}{|c|}{$\mathrm{RF} \geq 5$} & \multicolumn{2}{|c|}{$\mathrm{RF} \geq 3$} & \multicolumn{2}{|c|}{$\mathrm{RF} \geq 5$} & \multicolumn{2}{|c|}{$\mathrm{RF} \geq 3$} & \multicolumn{2}{|c|}{$\mathrm{RF} \geq 5$} & \multicolumn{2}{|c|}{$\mathrm{RF} \geq 1$} & \multicolumn{2}{|c|}{$\mathrm{RF} \geq 4$} & \multicolumn{2}{|c|}{$\mathrm{RF} \geq 1$} & \multicolumn{2}{|c|}{$\mathrm{RF} \geq 4$} \\
\hline & $\%$ & $\mathbf{N}$ & $\%$ & $\mathbf{N}$ & $\%$ & $\mathrm{~N}$ & $\%$ & $\mathbf{N}$ & $\%$ & $\mathrm{~N}$ & $\%$ & $\mathrm{~N}$ & $\%$ & $\mathbf{N}$ & $\%$ & $\mathbf{N}$ & $\%$ & $\mathbf{N}$ & $\%$ & $\mathrm{~N}$ \\
\hline AOSEPT PLUS & 83.3 & 12 & 66.7 & 12 & 100 & 6 & 100 & 6 & 83.3 & 12 & 50 & 12 & 100 & 6 & 100 & 6 & 100 & 6 & 100 & 6 \\
\hline BlueVision & 91.7 & 12 & 33.3 & 12 & 100 & 6 & 100 & 6 & 100 & 6 & 100 & 6 & 100 & 6 & 100 & 6 & 100 & 6 & 100 & 6 \\
\hline Easy Sept & 16.7 & 12 & 0 & 12 & 100 & 6 & 100 & 6 & 100 & 6 & 100 & 6 & 100 & 6 & 100 & 6 & 100 & 6 & 100 & 6 \\
\hline Oxysept Comfort & 0 & 6 & 0 & 6 & 100 & 6 & 100 & 6 & 100 & 6 & 100 & 6 & 100 & 6 & 100 & 6 & 100 & 6 & 100 & 6 \\
\hline Optifree Replenish & 91.7 & 12 & 0 & 12 & 100 & 6 & 100 & 6 & 100 & 12 & 33.3 & 12 & 83.3 & 6 & 0 & 6 & 91.7 & 12 & 83.3 & 12 \\
\hline Solocare Aqua & 0 & 12 & 0 & 12 & 58.3 & 12 & 16.7 & 12 & 0 & 6 & 0 & 6 & 50 & 6 & 0 & 6 & 100 & 12 & 58.3 & 12 \\
\hline$x^{2}$ test & \multicolumn{2}{|c|}{$<0.001$} & \multicolumn{2}{|c|}{$<0.001$} & \multicolumn{2}{|c|}{0.014} & \multicolumn{2}{|c|}{$<0.001$} & \multicolumn{2}{|c|}{$<0.001$} & \multicolumn{2}{|c|}{$<0.001$} & \multicolumn{2}{|c|}{0.03} & \multicolumn{2}{|c|}{$<0.001$} & \multicolumn{2}{|c|}{0.69} & \multicolumn{2}{|c|}{0.047} \\
\hline
\end{tabular}

The intervals $\geq 3.0 \mathrm{log}[\mathrm{CFU} / \mathrm{ml}]$ for bacteria and $\geq 1.0 \mathrm{log}[\mathrm{CFU} / \mathrm{ml}]$ for fungi were assessed according to the criteria of the EN ISO 14729 Stand Alone Test [47]. The intervals $\geq 5.0 \mathrm{log}$ [CFU/ml] for bacteria according to the criteria of the norms EN 1040 [58], EN 13727 [59] and EN 1276 [60] and $\geq 4.0$ log [CFU/ml] for fungi according to the criteria of the norms EN 1275 [61], EN 13624 [62] and EN 1650 [63] were assessed. 
Table 7 Proportions of reduction factors exceeding pre-specified thresholds for each CL care solution and for each tested microorganism after MMRDT

\begin{tabular}{|c|c|c|c|c|c|c|c|c|c|c|c|c|c|c|c|c|c|c|c|c|}
\hline & \multicolumn{4}{|c|}{ S. aureus } & \multicolumn{4}{|c|}{ P. aeruginosa } & \multicolumn{4}{|c|}{ S. marcescens } & \multicolumn{4}{|c|}{ C. albicans } & \multicolumn{4}{|c|}{ F. solani } \\
\hline & \multicolumn{2}{|c|}{$\mathrm{RF} \geq 3$} & \multicolumn{2}{|c|}{$\mathrm{RF} \geq 5$} & \multicolumn{2}{|c|}{$\mathrm{RF} \geq 3$} & \multicolumn{2}{|c|}{$\mathrm{RF} \geq 5$} & \multicolumn{2}{|c|}{$\mathrm{RF} \geq 3$} & \multicolumn{2}{|c|}{$\mathrm{RF} \geq 5$} & \multicolumn{2}{|c|}{$\mathrm{RF} \geq 1$} & \multicolumn{2}{|c|}{$\mathrm{RF} \geq 4$} & \multicolumn{2}{|c|}{$\mathrm{RF} \geq 1$} & \multicolumn{2}{|c|}{$\mathrm{RF} \geq 4$} \\
\hline & $\%$ & $\bar{N}$ & $\%$ & $\bar{N}$ & $\%$ & $\bar{N}$ & $\%$ & $\bar{N}$ & $\%$ & $\bar{N}$ & $\%$ & $\bar{N}$ & $\%$ & $\bar{N}$ & $\%$ & $\bar{N}$ & $\%$ & $\mathbf{N}$ & $\%$ & $\mathrm{~N}$ \\
\hline AOSEPT PLUS & 88.9 & 9 & 77.8 & 9 & 100 & 6 & 100 & 6 & 88.9 & 9 & 66.7 & 9 & 100 & 6 & 100 & 6 & 100 & 6 & 100 & 6 \\
\hline BlueVision & 66.7 & 9 & 22.2 & 9 & 100 & 6 & 100 & 6 & 100 & 6 & 100 & 6 & 100 & 6 & 100 & 6 & 100 & 6 & 100 & 6 \\
\hline Easy Sept & 11.1 & 9 & 0 & 9 & 100 & 6 & 100 & 6 & 100 & 6 & 100 & 6 & 100 & 6 & 100 & 6 & 100 & 6 & 100 & 6 \\
\hline Oxysept Comfort & 0 & 6 & 0 & 6 & 100 & 6 & 100 & 6 & 100 & 6 & 100 & 6 & 100 & 6 & 100 & 6 & 100 & 6 & 100 & 6 \\
\hline Optifree Replenish & 55.6 & 9 & 0 & 9 & 88.9 & 9 & 66.7 & 9 & 91.7 & 12 & 16.7 & 12 & 88.9 & 9 & 11.1 & 9 & 91.7 & 12 & 83.3 & 12 \\
\hline Solocare Aqua & 0 & 9 & 0 & 9 & 33.3 & 9 & 11.1 & 9 & 0 & 6 & 0 & 6 & 66.7 & 9 & 22.2 & 9 & 100 & 12 & 50 & 12 \\
\hline$x^{2}$ test & \multicolumn{2}{|c|}{$<0.001$} & \multicolumn{2}{|c|}{$<0.001$} & \multicolumn{2}{|c|}{0.001} & \multicolumn{2}{|c|}{$<0.001$} & \multicolumn{2}{|c|}{$<0.001$} & \multicolumn{2}{|c|}{$<0.001$} & \multicolumn{2}{|c|}{0.132} & \multicolumn{2}{|c|}{$<0.001$} & \multicolumn{2}{|c|}{0.69} & \multicolumn{2}{|c|}{0.013} \\
\hline
\end{tabular}

The intervals $\geq 3.0 \mathrm{log}$ [CFU/ml] for bacteria and $\geq 1.0 \mathrm{log}$ [CFU/ml] for fungi were assessed according to the criteria of the EN ISO 14729 Stand Alone Test [47]. The intervals $\geq 5.0$ log [CFU/ml] for bacteria according to the criteria of the norms EN 1040 [58], EN 13727 [59] and EN 1276 [60] and $\geq 4.0$ log [CFU/ml] for fungi according to the criteria of the norms EN 1275 [61], EN 13624 [62] and EN 1650 [63] were assessed.

surprisingly increases for most CL care solutions, and in particular for BlueVision and Optifree Replenish, which then pass the primary criteria of the Stand Alone Test. This increased efficacy has also been observed for Solocare Aqua against $P$. aeruginosa, whereas the presence of organic load seems to have no effect on the efficacies against $S$. marcescens and $F$. solani. In contrast, the yeast C. albicans was more resistant to the MPSs in the presence of the artificial tear fluid. This unequal effect on the disinfecting efficacies of the different CL care solutions can possibly be explained by the antimicrobial characteristics of lysozyme and other proteins in the artificial tear fluid. Lysozyme, also called $N$-acetylmuramidase, is an enzyme with antimicrobial activity against a wide range of microorganisms [83-88]. This enzyme catalyses the hydrolysis of $1.4-\beta$-bonds between $N$-acetylmuramic acid (NAM) and $N$-acetylglucosamine (NAG) residues in the peptidoglycan polymers of bacterial cells, also called murein, resulting in the lysis of the sensitive bacterial cells [83]. Mostly Gram-positive bacteria, such as $S$. aureus, are susceptible to lysozyme due to their freely accessible murein cell wall [83]. It has been reported that the antibacterial effect of lysozyme can vary between different bacterial species and strains and that it can be influenced by additional substances (lactoferrin, EDTA etc.) or changes in environmental conditions ( $\mathrm{pH}$ value, temperature, pressure, etc.) [83-88]. These influences may explain the findings in this study: the noticeably increased efficacy against the Gram-positive bacterium $S$. aureus, the slightly increased or lack of efficacy against the Gram-negative bacteria $P$. aeruginosa and S. marcescens, respectively. Through the observation that the artificial tear fluid used in this study influences the disinfecting efficacy of CL care solutions, especially that of MPSs, in a different way than do albumin, mucine or even the organic load suggested in EN ISO 14729, it becomes obvious that the test conditions in the EN ISO 14729 should be revised to create more realistic conditions, e.g., by using a more realistic artificial tear fluid.

Since the EN ISO 14729 was adopted in 2001, Kramer et al. [45] have criticised the following points: i. efficacy testing with organic load is only mentioned as an option

Table 8 Proportions of reduction factors exceeding pre-specified thresholds for each CL care solution and for each tested microorganism after overnight disinfection

\begin{tabular}{|c|c|c|c|c|c|c|c|c|c|c|c|c|c|c|c|c|c|c|c|c|}
\hline & \multicolumn{4}{|c|}{ S. aureus } & \multicolumn{4}{|c|}{ P. aeruginosa } & \multicolumn{4}{|c|}{ S. marcescens } & \multicolumn{4}{|c|}{ C. albicans } & \multicolumn{4}{|c|}{ F. solani } \\
\hline & \multicolumn{2}{|c|}{$\mathrm{RF} \geq 3$} & \multicolumn{2}{|c|}{$\mathrm{RF} \geq 5$} & \multicolumn{2}{|c|}{$\mathrm{RF} \geq 3$} & \multicolumn{2}{|c|}{$\mathrm{RF} \geq 5$} & \multicolumn{2}{|c|}{$\mathrm{RF} \geq 3$} & \multicolumn{2}{|c|}{$\mathrm{RF} \geq 5$} & \multicolumn{2}{|c|}{$\mathrm{RF} \geq 1$} & \multicolumn{2}{|c|}{$\mathrm{RF} \geq 4$} & \multicolumn{2}{|c|}{$\mathrm{RF} \geq 1$} & \multicolumn{2}{|c|}{$\mathrm{RF} \geq 4$} \\
\hline & $\%$ & $\mathrm{~N}$ & $\%$ & $\mathrm{~N}$ & $\%$ & $\mathrm{~N}$ & $\%$ & $\mathrm{~N}$ & $\%$ & $\mathrm{~N}$ & $\%$ & $\mathrm{~N}$ & $\%$ & $\mathrm{~N}$ & $\%$ & $\bar{N}$ & $\%$ & $\mathrm{~N}$ & $\%$ & $\mathrm{~N}$ \\
\hline AOSEPT PLUS & 88.9 & 9 & 77.8 & 9 & 100 & 6 & 100 & 6 & 88.9 & 9 & 66.7 & 9 & 100 & 6 & 100 & 6 & 100 & 6 & 100 & 6 \\
\hline BlueVision & 55.6 & 9 & 22.2 & 9 & 100 & 6 & 100 & 6 & 100 & 6 & 100 & 6 & 100 & 6 & 100 & 6 & 100 & 6 & 100 & 6 \\
\hline Easy Sept & 11.1 & 9 & 0 & 9 & 100 & 6 & 100 & 6 & 100 & 6 & 100 & 6 & 100 & 6 & 100 & 6 & 100 & 6 & 100 & 6 \\
\hline Oxysept Comfort & 0 & 6 & 0 & 6 & 100 & 6 & 100 & 6 & 100 & 6 & 100 & 6 & 100 & 6 & 100 & 6 & 100 & 6 & 100 & 6 \\
\hline Optifree Replenish & 66.7 & 9 & 0 & 9 & 100 & 9 & 100 & 9 & 100 & 12 & 25 & 12 & 100 & 9 & 22.2 & 9 & 100 & 12 & 91.7 & 12 \\
\hline Solocare Aqua & 0 & 9 & 0 & 9 & 44.4 & 9 & 11.1 & 9 & 0 & 6 & 0 & 6 & 88.9 & 9 & 22.2 & 9 & 100 & 12 & 66.7 & 12 \\
\hline$x^{2}$ test & \multicolumn{2}{|c|}{$<0.001$} & \multicolumn{2}{|c|}{$<0.001$} & \multicolumn{2}{|c|}{0.001} & \multicolumn{2}{|c|}{$<0.001$} & \multicolumn{2}{|c|}{$<0.001$} & \multicolumn{2}{|c|}{$<0.001$} & \multicolumn{2}{|c|}{0.585} & \multicolumn{2}{|c|}{$<0.001$} & \multicolumn{2}{|c|}{1} & \multicolumn{2}{|c|}{0.087} \\
\hline
\end{tabular}

The intervals $\geq 3.0 \mathrm{log}$ [CFU/ml] for bacteria and $\geq 1.0 \mathrm{log}$ [CFU/ml] for fungi were assessed according to the criteria of the EN ISO 14729 Stand Alone Test [47]. The intervals $\geq 5.0 \mathrm{log}$ [CFU/ml] for bacteria according to the criteria of the norms EN 1040 [58], EN 13727 [59] and EN 1276 [60] and $\geq 4.0$ log [CFU/ml] for fungi according to the criteria of the norms EN 1275 [61], EN 13624 [62] and EN 1650 63] were assessed. 
and the type of organic load is not specified; ii. for bacteria, the test protocol neither includes data on the standard deviation nor on the number of test reproductions necessary for statistical significance; iii. a RF of 1 $\log$ unit for $C$. albicans and F. solani cannot be exactly ascertained experimentally and falls within the scatter range of the quantitative suspension test $( \pm 0.5 \mathrm{log})$; iv. neutralisation testing is not adequately defined and must be described more precisely; v. testing against Acanthamoeba species is not recommended but should be defined with a RF of at least $>2$ log units; vi. compared to other harmonised norms, the required RFs are too for evaluating the microbicidal efficacy of disinfectants; vii. a test under practical conditions (Regimen Test) is only required if the primary criteria of the Stand Alone Test are not met. Further critical points must be considered when testing CL care solution: i. laboratory strains may be inadequate for assuring that the CL care solutions will be equally effective against clinical isolates [41,66,68,89-91].; ii. After extended periods of storage, the disinfecting efficacy of polyhexanide-based MPSs may decrease due to the accumulation of polyhexanide on the CL material or CL case [70,92]; iii. higher storage temperatures can lead to decreased disinfecting efficacies [93]; longer storage times of open hydrogen-peroxidebased CL care solutions can lead to a decrease of the hydrogen peroxide concentration and thus decreased disinfecting efficacy.

Bearing a number of these influences in mind, some changes were incorporated into the EN ISO 14729 [94] in 2010: i. clarification of the criteria of the Stand Alone Test for moulds (CL care solution direct test); ii. changes in the recommendations regarding the rub-and-/or-rinse steps to the effect that if the CL care solution can be used without a rub and-/or-rinse step according to the manufacturer's instructions, the CL care solution must pass the secondary criteria of the Stand Alone Test as well as the criteria of the Regimen Test in the presence of organic load; iii. incorporation of requirements for testing CL care solutions for use on silicone hydrogel CLs. Despite these changes, the aspects which have been criticised in the past still have not been adequately addressed in this amendment. Especially the demands for i. stricter reduction factors, ii. a quantitative suspension with and without organic load in combination with a test simulating practical conditions, and iii. a specified and realistic artificial tear fluid as organic load have been neglected.

In the European test hierarchy for chemical disinfectants and antiseptics, stricter reduction factors of $\geq 5 \log$ units for bacteria and $\geq 4 \log$ units for fungi are recommended in each test norm regardless of the type of test (quantitative suspension test or practical setting). These harmonised requirements could also be adequate criteria for the determination of the efficacies of $\mathrm{CL}$ care solutions. Furthermore, the European test hierarchy is a system of three tests: phase 1 (quantitative suspension test without organic load); phase 2 step 1 (quantitative suspension test with organic load); phase 2 step 2 (carrier test - practical settings). All three tests must be performed and passed in order to determine the bactericidal and fungicidal efficacies of chemical disinfectants and antiseptics. This system is another improvement that could be made in the testing of CL care solutions. Moreover, improvements to the Regimen Test as a phase 2 steps 2 test have recently been suggested in order to provide a more realistic evaluation of applicable CL care disinfecting solutions [95].

\section{Conclusions}

Because artificial tear fluid influences the disinfecting efficacy of contact lens care solutions, especially that of multi-purpose solutions, in a different way than does albumin, mucine, or the organic load suggested in EN ISO 14729, it becomes obvious that the test conditions in the EN ISO 14729 should be revised in order to create more realistic conditions, e.g., by using a more realistic artificial tear fluid. Furthermore, we suggest adapting the EN ISO 14729 to the European test hierarchy for chemical disinfectants and antiseptics, which consists of three test phases and also requests meeting stricter criteria in order to pass the test.

The CL industry itself has also started to respond to the criticism by enhancing their CL care products, e.g., AMO Eyecare with its product COMPLETE ${ }^{\circledR}$ RevitaLens, Alcon's Opti-Free EverMoist or Bausch \& Lomb's Biotrue $^{\mathrm{TM}}$. These three products have an increased concentration of active ingredients, combinations of active ingredients have been introduced (polyquad together with another active ingredient such as a biguanide or an amidoamine), and the recommendation to perform an adequate rub-and-rinse step has been revived. However, it is not expected that the compliance rate of CL wearers with their CL care regimen will increase considerably, and, therefore, the criteria to evaluate the disinfecting efficacy of CL care products must be made substantially more rigorous and a certain safety margin should be included. Critical CL care products would then disappear from the market leaving those products that exhibit an adequate disinfecting efficacy. This way it is possible to counteract the careless behaviour of the great majority of CL wearers and the risk of CL-related microbial keratitis and other infections will be decreased.

\section{Competing interests}

The authors declare that they have no competing interests.

\section{Authors' contributions}

$\mathrm{CH}$ and AK designed the study. AK coordinated the study. DW performed the quantitative suspension tests. TK was responsible for statistical analysis and interpretation of the data. $\mathrm{CH}$ wrote the manuscript and $\mathrm{CH}, \mathrm{DW}$, TK and 
AK were involved in drafting the manuscript and revising it critically for important intellectual content. All authors have read and approved the final manuscript.

\section{Acknowledgment}

The authors would like to thank the Transfusion Medicine Center of the University of Greifswald for providing human blood serum samples and Fielmann AG (Hamburg, Germany) and Fielmann Akademie (Plön, Germany) for providing $\mathrm{CL}$ and $\mathrm{CL}$ care solution samples. This research was conducted with the financial support of ANOVIS Biotech GmbH (Ahlen, Germany).

\section{Author details}

${ }^{1}$ Institute of Hygiene and Environmental Medicine, University Medicine Greifswald, Greifswald, Germany. ${ }^{2}$ Institute of Community Medicine, University Medicine Greifswald, Greifswald, Germany.

Received: 23 April 2012 Accepted: 1 October 2012

Published: 3 October 2012

\section{References}

1. Fleiszig SM, Evans DJ: Pathogenesis of contact lens-associated microbial keratitis. Optom Vis Sci 2010, 87(4):225-232.

2. Fleiszig SM, Evans DJ: Contact lens infections: can they ever be eradicated? Eye Contact Lens 2003, 29(1 Suppl):S67-71. discussion S83-64, S192-194.

3. Morgan PB, Efron N, Hill EA, Raynor MK, Whiting MA, Tullo AB: Incidence of keratitis of varying severity among contact lens wearers. $\mathrm{Br} J$ Ophthalmol 2005, 89(4):430-436.

4. Erie JC, Nevitt MP, Hodge DO, Ballard DJ: Incidence of ulcerative keratitis in a defined population from 1950 through 1988. Arch Ophthalmol 1993, 111(12):1665-1671.

5. Bourcier T, Thomas F, Borderie V, Chaumeil C, Laroche L: Bacterial keratitis: predisposing factors, clinical and microbiological review of 300 cases. $\mathrm{Br}$ J Ophthalmol 2003, 87(7):834-838.

6. Alfonso E, Mandelbaum S, Fox MJ, Forster RK: Ulcerative keratitis associated with contact lens wear. Am J Ophthalmol 1986, 101(4):429-433.

7. Bowden FW, Cohen EJ, Arentsen JJ, Laibson PR: Patterns of lens care practices and lens product contamination in contact lens associated microbial keratitis. CLAO J 1989, 15(1):49-54.

8. Grant T, Chong MS, Vajdic C, Swarbrick HA, Gauthier C, Sweeney DF, Holden $\mathrm{BA}$ : Contact lens induced peripheral ulcers during hydrogel contact lens wear. CLAO J 1998, 24(3):145-151.

9. Schein OD, Glynn RJ, Poggio EC, Seddon JM, Kenyon KR: The relative risk of ulcerative keratitis among users of daily-wear and extended-wear soft contact lenses. A case-control study. Microbial Keratitis Study Group. N Engl J Med 1989, 321(12):773-778.

10. Schein OD, Poggio EC: Ulcerative keratitis in contact lens wearers. Incidence and risk factors. Cornea 1990, 9(Suppl 1):S55-S58. discussion S62-53.

11. Moriyama AS, Hofling-Lima AL: Contact lens-associated microbial keratitis. Ara Bras Oftalmol 2008, 71(6 Suppl):32-36.

12. Nzeako BC, Al-Sumri SH: The disinfecting potential of contact lens soutions used by Sultan Qaboos University students. Sultan Qaboos Univ Med J 2011, 11(2):252-258.

13. Kramer A, Höh H, Roth HW, Rudolph P, Schnell D, Tost F, Werner HP: [Incidence, Causes and Prevention of Contact-Lens-Associated Infectious Keratitis. Hyg Med 2002, 27(11):438-449.

14. Stapleton F, Keay LJ, Sanfilippo PG, Katiyar S, Edwards KP, Naduvilath T: Relationship between climate, disease severity, and causative organism for contact lens-associated microbial keratitis in Australia. Am J Ophthalmol 2007, 144(5):690-698.

15. Willcox MD, Power KN, Stapleton F, Leitch C, Harmis N, Sweeney DF: Potential sources of bacteria that are isolated from contact lenses during wear. Optom Vis Sci 1997, 74(12):1030-1038.

16. Willcox MD, Carnt N, Diec J, Naduvilath T, Evans V, Stapleton F, Iskandar S, Harmis N, de la Jara PL, Holdenp BA: Contact lens case contamination during daily wear of silicone hydrogels. Optom Vis Sci 2010, 87(7):456-464.

17. Kanpolat A, Kalayci D, Arman D, Duruk K: Contamination in contact lens care systems. CLAO J 1992, 18(2):105-107.
18. Wilson LA, Sawant AD, Simmons RB, Ahearn DG: Microbial contamination of contact lens storage cases and solutions. Am J Ophthalmol 1990, 110 (2):193-198.

19. Yung MS, Boost M, Cho P, Yap M: Microbial contamination of contact lenses and lens care accessories of soft contact lens wearers (university students) in Hong Kong. Ophthalmic Physiol Opt 2007, 27(1):11-21.

20. Brewitt H: [Contact lenses. Infections and hygiene]. Ophthalmologe 1997, 94(5):311-316.

21. Szczotka-Flynn LB, Pearlman E, Ghannoum M: Microbial contamination of contact lenses, lens care solutions, and their accessories: a literature review. Eye Contact Lens 2010, 36(2):116-129.

22. Pleyer U, Behrens-Baumann W: [Bacterial keratitis. Current diagnostic aspects]. Ophthalmologe 2007, 104(1):9-14.

23. Sweeney DF, Stapleton F, Leitch C, Taylor J, Holden BA, Willcox MD: Microbial colonization of soft contact lenses over time. Optom Vis Sci 2001, 78(2):100-105.

24. Willcox MD, Harmis N, Cowell BA, Williams T, Holden BA: Bacterial interactions with contact lenses; effects of lens material, lens wear and microbial physiology. Biomaterials 2001, 22(24):3235-3247.

25. Rudolph P, Adams C, Jülich WD, Kramer A, Metelmann C, Werner HP: [Contact lens fitting - a source for infectious of the eye]. Contactologia 1996, 18D(3):189-195.

26. Callender MG, Charles AM, Chalmers RL: Effect of storage time with different lens care systems on in-office hydrogel trial lens disinfection efficacy: a multi-center study. Optom Vis Sci 1992, 69(9):678-684.

27. Collins M, Coulson J, Shuley V, Bruce A: Contamination of disinfection solution bottles used by contact lens wearers. CLAO J 1994, 20(1):32-36

28. Bilgin LK, Manav G, Tutkun IT, Oner A, Ertoprak Y: Efficacy of a one-step hydrogen peroxide system for disinfection of soft contact lenses. CLAO J 1993, 19(1):50-52.

29. Dutot M, Paillet H, Chaumeil C, Warnet JM, Rat P: Severe ocular infections with contact lens: role of multipurpose solutions. Eye (Lond) 2009, 23 (2):470-476.

30. Guillon M, Maissa C: Use of silicone hydrogel material for daily wear. Cont Lens Anterior Eye 2007, 30(1):5-10. quiz 71.

31. Ward SK, Dogru M, Wakamatsu T, Ibrahim O, Matsumoto Y, Kojima T, Sato EA, Ogawa J, Schnider C, Negishi K, et al: Passive cigarette smoke exposure and soft contact lens wear. Optom Vis Sci 2010, 87(5):367-372.

32. Brennan NA, Coles ML: Continuous wear. In Contact Lens Practice vol. 26: Butterworth Heinemann Elsevier. Edited by Efron N. 2010:266-280.

33. Claydon BE, Efron N: Non-compliance in contact lens wear. Ophthalmic Physiol Opt 1994, 14(4):356-364.

34. Key JE, Monnat K: Comparative disinfectant efficacy of two disinfecting solutions against Pseudomonas aeruginosa. CLAO $J$ 1996, 22(2):118-121.

35. Wu Y, Carnt N, Stapleton F: Contact lens user profile, attitudes and level of compliance to lens care. Cont Lens Anterior Eye 2010, 33(4):183-188.

36. Efron N: Compliance. In Contact Lens Practice vol. 6: Butterworth Heinemann Elsevier. Edited by Efron N. 2010:427-432.

37. Donshik PC, Ehlers WH, Anderson LD, Suchecki JK: Strategies to better engage, educate, and empower patient compliance and safe lens wear: compliance: what we know, what we do not know, and what we need to know. Eye Contact Lens 2007, 33(6 Pt 2):430-433. discussion 434.

38. Patel DV, Rayner S, McGhee CN: Resurgence of Acanthamoeba keratitis in Auckland, New Zealand: a 7-year review of presentation and outcomes. Clin Experiment Ophthalmol 2010, 38(1):15-20. quiz 87.

39. Hasler S, Dedes W, Mathis A, Grimm F, Thiel MA: MoisturePlus contact lens solution as a source of acanthamoeba keratitis. Cornea 2009, 28(2):219220.

40. Patel A, Hammersmith K: Contact lens-related microbial keratitis: recent outbreaks. Curr Opin Ophthalmol 2008, 19(4):302-306.

41. Hume EB, Flanagan J, Masoudi S, Zhu H, Cole N, Willcox MD: Soft contact lens disinfection solution efficacy: clinical Fusarium isolates vs. ATCC 36031. Optom Vis Sci 2009, 86(5):415-419.

42. Proenca-Pina J, Ssi Yan Kai I, Bourcier T, Fabre M, Offret H, Labetoulle M: Fusarium keratitis and endophthalmitis associated with lens contact wear. Int Ophthalmol 2010, 30(1):103-107.

43. Ide T, Miller D, Alfonso EC, O'Brien TP: Impact of contact lens group on antifungal efficacy of multipurpose disinfecting contact lens solutions. Eye Contact Lens 2008, 34(3):151-159. 
44. Saltzmann RM, Yep JM, Blomquist PH: Fusarium keratitis associated with ReNu with MoistureLoc sample kits. Eye Contact Lens 2008, 34(6):337-339.

45. Kramer A, Rudolph P, Werner HP: Antimicrobial efficacy of contact lens care products and critical comment on ISO/FDIS 14729. Dev Ophthalmol 2002, 33:343-361.

46. Kramer A, Wernet M, Rudolph P, Werner HP, Adam C, Jülich WD: [Fitting soft contact lenses: a neglected infection hazard]. Hyg Med 1995, 20 (6):278-291

47. EN ISO 14729: Ophthalmic optics - Contact lens care products Microbiological requirements and test methods for products and regimens for hygienic management of contact lenses. 2001

48. Council directive 93/42/EEC of 14 June 1993 concerning medical devices. 2007

49. Rosenthal RA, Sutton SV, Schlech BA: Review of standard for evaluating the effectiveness of contact lens disinfectants. PDA J Pharm Sci Technol 2002, 56(1):37-50.

50. Lever AM, Miller MJ: Comparative antimicrobial efficacy of multi-purpose lens care solutions using the FDA's revised guidance document for industry: stand-alone primary criteria. CLAO J 1999, 25(1):52-56.

51. Scheuer C, Zhao F, Erb T, Orsborn G: Multipurpose solutions and rates of biocidal efficacy. Eye Contact Lens 2009, 35(2):88-91.

52. Manuj K, Gunderson C, Troupe J, Huber ME: Efficacy of contact lens disinfecting solutions against Staphylococcus aureus and Pseudomonas aeruginosa. Eye Contact Lens 2006, 32(4):216-218.

53. Schneider A: In-vitro Prüfung der mikrobioziden Wirksamkeit von 17 Kontaktlinsenpflegesystemen für weiche Linsen auf Basis der DIN 14729, PhD thesis. Ernst Moritz Arndt University Greifswald, Department of Hygiene and Environmental Medicine. 2007.

54. Van Haeringen NJ: Clinical biochemistry of tears. Surv Ophthalmol 1981, 26 (2):84-96.

55. Geerling G, Maclennan S, Hartwig D: Autologous serum eye drops for ocular surface disorders. Br J Ophthalmol 2004, 88(11):1467-1474.

56. Farris RL: Tear analysis in contact lens wearers. Trans Am Ophthalmol SoC 1985, 83:501-545.

57. Sariri R, Ghafoori H: Tear proteins in health, disease, and contact lens wear. Biochemistry (Mosc) 2008, 73(4):381-392.

58. EN 1040: Chemical disinfectants and antiseptics - Quantitative suspension test for the evaluation of basic bactericidal activity of chemical disinfectants and antiseptics - Test method and requirements (phase 1). 2005.

59. prEN 13727: Chemical disinfectants and antiseptics - Quantitative suspension test for the evaluation of bactericidal activity in the medical area - Test method and requirements (phase 2, step 1). 2009.

60. EN 1276: Chemical disinfectants and antiseptics - Quantitative suspension test for the evaluation of bactericidal activity of chemical disinfectants and antiseptics used in food, industrial, domestic and institutional areas - Test method and requirements (phase 2, step 1). 2009.

61. EN 1275: Chemica/ disinfectants and antiseptics - Quantitative suspension test tor the evaluation of basic fungicidal or basic yeasticidal activity of chemical disinfectants and antiseptics - Test method and requirements (phase 1). 2005.

62. prEN 13624: Chemical disinfectants and antiseptics - Quantitative suspension test for the evaluation of fungicidal and yeasticidal activity in the medical area - Test method and requirements (phase2, step 1). 2010.

63. EN 1650: Chemical disinfectants and antiseptics - Quantitative suspension test for the evaluation of fungicidal or yeasticidal activity of chemical disinfectants and antiseptics used in food, industrial, domestic and institutional areas - Test method and requirements (phase 2, step 1). 2008.

64. Imamura Y, Chandra J, Mukherjee PK, Lattif AA, Szczotka-Flynn LB, Pearlman E, Lass JH, O'Donnell K, Ghannoum MA: Fusarium and Candida albicans biofilms on soft contact lenses: model development, influence of lens type, and susceptibility to lens care solutions. Antimicrob Agents Chemother 2008, 52(1):171-182.

65. Retuerto MA, Szczotka-Flynn L, Ho D, Mukherjee P, Ghannoum MA: Efficacy of care solutions against contact lens-associated Fusarium biofilms. Optom Vis Sci 2012, 89(4):382-391.

66. Boost M, Lai S, Ma C, Cho P: Do multipurpose contact lens disinfecting solutions work effectively against non-FDA/ISO recommended strains of bacteria and fungi? Ophthalmic Physiol Opt 2010, 30(1):12-19.

67. Parment PA, Colucci B, Nystrom B: The efficacy of soft contact lens disinfection solutions against Serratia marcescens and Pseudomonas aeruginosa. Acta Ophthalmol Scand 1996, 74(3):235-237.
68. Hume EB, Zhu H, Cole N, Huynh C, Lam S, Willcox MD: Efficacy of contact lens multipurpose solutions against serratia marcescens. Optom Vis Sci 2007, 84(4):316-320.

69. Santodomingo-Rubido J, Mori O, Kawaminami S: Cytotoxicity and antimicrobial activity of six multipurpose soft contact lens disinfecting solutions. Ophthalmic Physiol Opt 2006, 26(5):476-482.

70. Dannelly HK, Waworuntu RV: Effectiveness of contact lens disinfectants after lens storage. Eye Contact Lens 2004, 30(3):163-165.

71. Amiri MA, Mohammadinia M, Tabatabaee M, Askarizadeh F, Behgozin A: Comparative efficacies of contact lens disinfecting solutions against Pseudomonas aeruginosa. Clin Exp Optom 2011, 94(4):348-351.

72. Codling CE, Maillard JY, Russell AD: Performance of contact lens disinfecting solutions against Pseudomonas aeruginosa in the presence of organic load. Eye Contact Lens 2003, 29(2):100-102.

73. Steinert J: Ins Auge gegangen, Ökotest. Frankfurt.: ; 2004

74. Liotet $\mathrm{S}$, Feurer $\mathrm{B}$ : The use of $3 \%$ hydrogen peroxide for sterilisation of soft hydrophilic contact lenses. Contactologia 1984, 4(6):178-180.

75. Lowe $R$, Vallas $V$, Brennan NA: Comparative efficacy of contact lens disinfection solutions. CLAO J 1992, 18(1):34-40.

76. Schunk T, Schweisfurth R: [Disinfectant performance of oxidizing hygiene systems on organically contaminated contact lenses. Contactologia 1989, 11D:90-95.

77. Rosenthal RA, Stein JM, McAnally CL, Schlech BA: A comparative study of the microbiologic effectiveness of chemical disinfectants and peroxideneutralizer systems. CLAO J 1995, 21(2):99-110.

78. Morgan PB: Soft lens care systems. In Contact Lens Practice vol. 2: Butterworth Heinemann Elsevier. Edited by Efron N.; 2010:128-141.

79. Heaselgrave W, Andrew PW, Kilvington S: Acidified nitrite enhances hydrogen peroxide disinfection of Acanthamoeba, bacteria and fungi. $J$ Antimicrob Chemother 2010, 65(6):1207-1214.

80. Yanai R, Ueda K, Nishida T, Toyohara M, Mori O: Effects of ionic and surfactant agents on the antimicrobial activity of polyhexamethylene biguanide. Eye Contact Lens 2011, 37(2):85-89.

81. Yanai R, Ueda K, Nishida T, Toyohara M, Mori O: Effects of tonicityadjusting and surfactant agents on the antimicrobial activity of alexidine. Eye Contact Lens 2011, 37(2):57-60.

82. McGrath D, Costanzo SP, Manchester RJ, Kaiser JJ, Norton SE, McCormick PJ: Comparative antimicrobial activity of no-rub multipurpose lens care solutions in the presence of organic soil. Eye Contact Lens 2003, 29(4):245-249.

83. Benkerroum N: Antimicrobial activitiy of lysozyme with special relevance to milk. Afr J Biotechnol 2008, 7(25):4856-4867

84. Ramanauskiene K, Inkeniene AM, Savickas A, Masteikova R, Brusokas V: Analysis of the antimicrobial activity of propolis and lysozyme in semisolid emulsion systems. Acta Pol Pharm 2009, 66(6):681-688.

85. Masschalck B, Deckers D, Michiels CW: Lytic and nonlytic mechanism of inactivation of gram-positive bacteria by lysozyme under atmospheric and high hydrostatic pressure. J Food Prot 2002, 65(12):1916-1923.

86. Masschalck B, Michiels CW: Antimicrobial properties of lysozyme in relation to foodborne vegetative bacteria. Crit Rev Microbiol 2003, 29(3):191-214

87. Masschalck B, Van Houdt R, Van Haver EG, Michiels CW: Inactivation of gram-negative bacteria by lysozyme, denatured lysozyme, and lysozyme-derived peptides under high hydrostatic pressure. Appl Environ Microbiol 2001, 67(1):339-344.

88. Nakimbugwe D, Masschalck B, Atanassova M, Zewdie-Bosuner A, Michiels CW: Comparison of bactericidal activity of six lysozymes at atmospheric pressure and under high hydrostatic pressure. Int J Food Microbiol 2006, 108(3):355-363.

89. Lakkis C, Fleiszig SM: Resistance of Pseudomonas aeruginosa isolates to hydrogel contact lens disinfection correlates with cytotoxic activity. J Clin Microbiol 2001, 39(4):1477-1486.

90. Mohammadinia M, Rahmani S, Eslami G, Ghassemi-Broumand M, Aghazadh Amiri M, Aghaie G, Tabatabaee SM, Taheri S, Behgozin v: Contact lens disinfecting solutions antibacterial efficacy: comparison between clinical isolates and the standard ISO ATCC strains of Pseudomonas aeruginosa and Staphylococcus aureus. Eye (Lond) 2011, 26(2):327-330.

91. Bruinsma GM, Rustema-Abbing M, van der Mei HC, Lakkis C, Busscher $\mathrm{HJ}$ : Resistance to a polyquaternium-1 lens care solution and isoelectric points of Pseudomonas aeruginosa strains. J Antimicrob Chemother 2006, 57(4):764-766. 
92. Rosenthal RA, McDonald MM, Schlitzer RL, Abshire R, Stone R: Loss of bactericidal activity from contact lens storage solutions. CLAO J 1997, 23(1):57-62

93. Bullock JD, Warwar RE, Elder BL, Northern WI: Temperature instability of ReNu With MoistureLoc: a new theory to explain the worldwide Fusarium keratitis epidemic of 2004-2006. Arch Ophthalmol 2008, 126(11):1493-1498.

94. EN ISO 14729: Ophthalmic optics - Contact lens care products -

Microbiological requirements and test methods for products and regimens for hygienic management of contact lenses. 2010.

95. Mowrey-McKee M, Borazjani R, Collins G, Cook J, Norton S: A new method for evaluation of compatibility of contact lenses and lens cases with contact lens disinfecting solutions. Eye Contact Lens 2012, 38(1):53-62.

doi:10.1186/1471-2334-12-241

Cite this article as: Hildebrandt et al:: In-vitro analysis of the microbicidal activity of 6 contact lens care solutions. BMC Infectious Diseases 2012 $12: 241$

\section{Submit your next manuscript to BioMed Central and take full advantage of:}

- Convenient online submission

- Thorough peer review

- No space constraints or color figure charges

- Immediate publication on acceptance

- Inclusion in PubMed, CAS, Scopus and Google Scholar

- Research which is freely available for redistribution 